\title{
Immunoglobulin Light Chain
}

National Cancer Institute

\section{Source}

National Cancer Institute. Immunoglobulin Light Chain. NCI Thesaurus. Code C16720.

A protein complex that consists of two light chains (kappa and lambda). The light chain molecules are of the same structure and composition, consisting of constant, variable, and hypervariable regions. 